\title{
Formation of Professional Intentions of Young People in the Conditions of Personality-Oriented Education in $\mathrm{SPbPU}$
}

\author{
Dmitrii Tikhonov \\ Graduate school of business and management \\ Peter the Great St. Petersburg Polytechnic University \\ Saint-Petersburg, Russia \\ dvtikhonov@spbstu.ru \\ Ilona Pankina \\ Graduate school of biotechnology and food science \\ Peter the Great St. Petersburg Polytechnic University \\ Saint-Petersburg, Russia \\ pankina_ia@spbstu.ru
}

\author{
Yulia Bazarnova \\ Graduate school of biotechnology and food science \\ Peter the Great St. Petersburg Polytechnic University \\ Saint-Petersburg, Russia \\ jbazarnova@spbstu.ru \\ Elena Belokurova \\ Graduate school of biotechnology and food science \\ Peter the Great St. Petersburg Polytechnic University \\ Saint-Petersburg, Russia \\ belokurova_es@spbstu.ru
}

\begin{abstract}
The article describes the need to train highly qualified specialists sought after on the global labor market. Scientific and technical progress in a market economy places high demands on young professionals. In order to meet the requirements of the time, young people need to constantly update their knowledge, self-develop and improve. The choice of profession is a crucial stage in the life of every young person. Parents help young people to choose a profession.

A large role in the choice of profession is played by various career guidance events held by universities. Modern higher education institutions offer a whole range of activities that contribute to the professional self-determination of students. Most activities are for students. But schoolchildren can participate in many activities. These are olympiads, quizzes, contests, exhibitions, open days, where schoolchildren can get an idea of their future profession.

To increase the effectiveness of career guidance work, it is necessary to introduce a "school-university" scheme more widely. Interactive events such as workshops, meetings with renowned scientists and experts in various fields of science are very popular now at St. Petersburg Polytechnic University. This approach allows young people to better navigate the choice of their future profession
\end{abstract}

Keywords: Russian education, youth, choice of profession, motivation, career guidance, active methods of interaction, competitive specialists

\section{INTRODUCTION}

The main distinctive feature of the Russian education development at the present stage is its continuity, which provides the unity and integrity of the pre-university, university and postgraduate training $[1,2]$.

According to the "National Doctrine of Education in the Russian Federation" (Decree of the Government of the Russian Federation of October 4, 2000 N 751) for the period up to 2025, it is noted that the continuity of education throughout a person's life and the succession of levels and stages of education are included in the educational goals.

By continuous education, one understands the consistent formation of the abilities and creative potential of specialists who are ready to work in constantly changing external conditions using the high-tech equipment, who are able to independently assess the situation and make responsible decisions.

The rapid growth of scientific and technical progress, the transition from a planned economy to a market economy and the acceleration of the development of society as a whole change the demand for the qualification structure of professional personnel, demanding from them professional mobility and perfection, the need to constantly update their knowledge, self-develop and improve $[3,4,5]$.

Therefore, the current education system in Russia, including a professional one, is focused on integration into the European educational space. According to the countries members of the European Union, in the XXI Europe entered a new era, which was called the "Age of Knowledge". This was stated at the meeting of the European Council in Lisbon in March 2000. The "lifelong learning" based on knowledge is 
The "school-university" system, which is a multi-level structure of higher education, opens up new opportunities not only for the interaction of general educational institutions with universities but also ensures more successful development of a harmonious and diversified personality.

The state importance and the socio-economic significance of the problems associated with the self-determination of young people have caused great activity of scientists and experts in various fields of knowledge, working to improve and further develop a number of aspects of carrier guidance.

Modern higher education institutions offer a whole range of activities that contribute to the professional selfdetermination of students [13].

\section{RESUlTS}

Saint Petersburg Polytechnic University offers a multilevel and multidirectional career guidance activity, the scheme of which is presented in Figure 1.

This scheme presents only a part of SPbPU activities that help schoolchildren, applicants, and students to actively acquire knowledge and skills, and improve them. This is useful in further practical activities after graduation.

All methods of career guidance activities are divided into passive and active. The first ones are aimed at holding events related to the informational advancement of the directions of educational programs of the university. These include open days, lectures on the types of professions, thematic evenings with the participation of invited professionals, the preparation and distribution of printed products showing the directions and profiles of the university; the university scientists appearance in the media, etc.

The activities of the second type are aimed at the active involvement of schoolchildren in the activities of the world of professions, science, and students. The following activities are recognized at SPbPU as particularly effective: Summer Schools and Intensives, Academies in Educational Directions, Olympiads, engineering creativity development activities (at the site of FABLAB-Polytech), scientific skill competitions, master classes, workshops held with students.

In events with schoolchildren held within the walls of SPbPU, a large role is given to active teaching methods when schoolchildren interact with each other and enter into dialogue [14]. Game methods are very popular among younger schoolchildren, when their team members are assigned to their roles in the performance of an assignment. In such conditions, participants learn new experiences, new roles, form communicative skills, the ability to apply acquired knowledge in various fields, the ability to solve problems, tolerance, and responsibility.

Schoolchildren are actively involved in this activity, they show great interest and readiness to take part in organized events, and are full of strength and creative ideas. They only need interest and support. And here the main task is instructing trainees, identifying their potential and the mood for productive activities. At the same time, the most important component is the professionalism and willingness of 


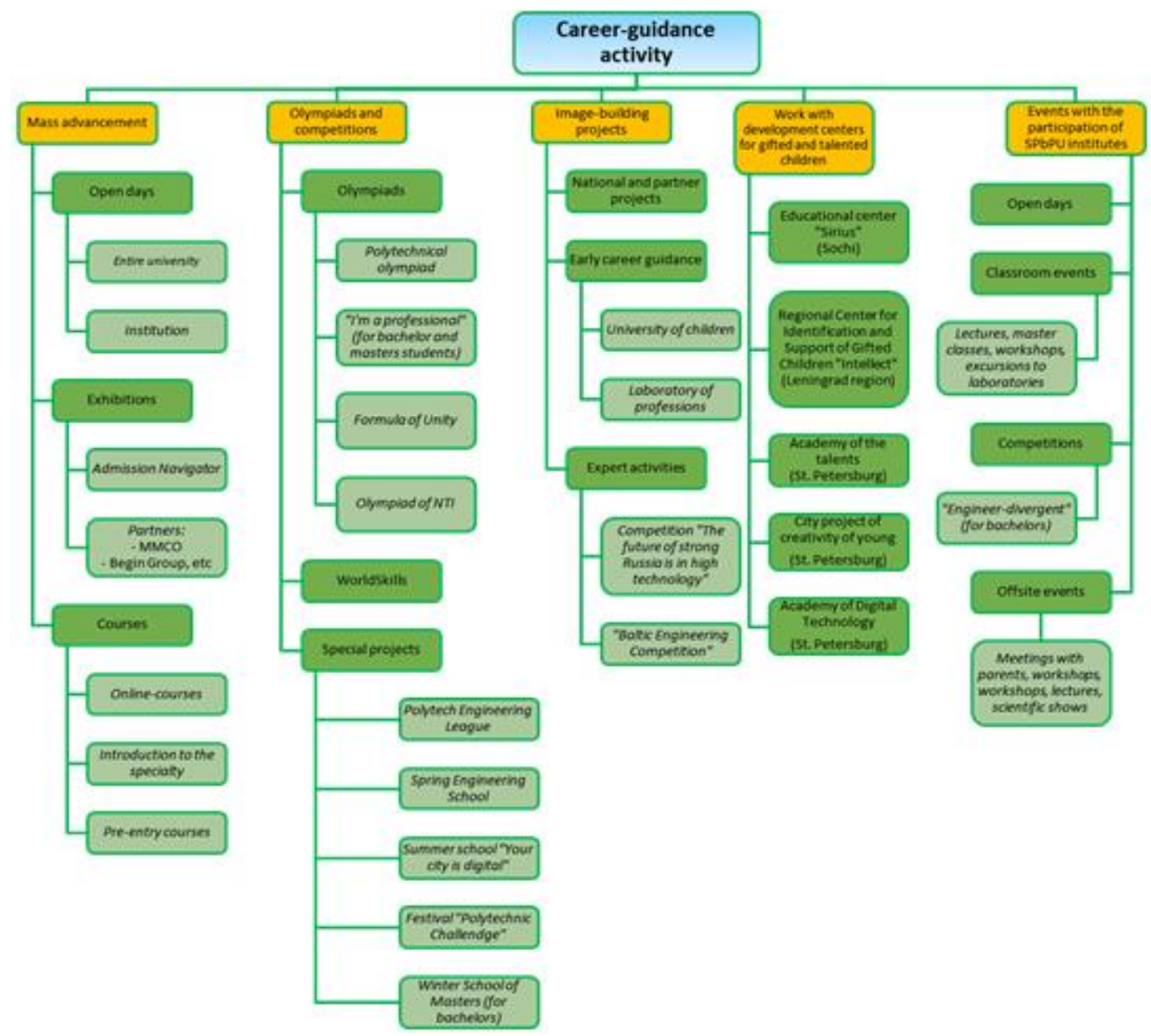

Fig, 1, Scheme of the activities of career orientation, implemented in SPbPU

employees and teachers of higher education institutions to be, to some extent, innovators, who carry along with themselves pupils and colleagues and create an active scientific and creative space around themselves.

With an appropriate choice of forms and methods of career guidance activities at a higher education institution, more productive involvement of applicants in higher education institutions that are in demand in the labor market in the future takes place.

Therefore, it is very important to attract to this problem employers who have a real and competent understanding of the current socio-economic situation in the country. At St. Petersburg Polytechnic University, such forms of interaction are very popular. These are meetings with real engineering workers of the leading enterprises of the region. During such meetings, they, as potential employers, are involved in career guidance activities as partners of specialized contests or competitions, or as jury members, as representatives of the business elite and a vivid example of professional success for the younger generation.

The implemented career guidance activities of our university result in the so-called "funnel of engagement", which shows the correlation between the number of young people involved in various activities and the number of admissions to SPbPU during the admission campaign of 20172018 (Figure 2).

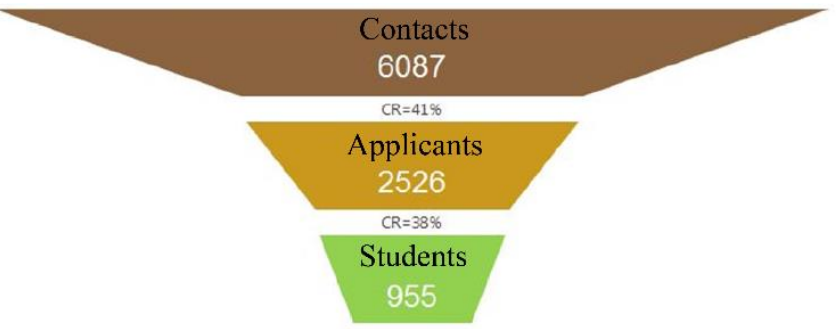

Fig, 2, "Funnel of engagement" during the admission campaign of 20172018

The analysis of the chart revealed that 6,086 people were involved in the events. Of these, 2,526 became applicants of SPbPU (7.6\% of the total number for 2016-2018), i.e. $41 \%$ of contacts were converted to applicants. Of these, $38 \%$ successfully entered and became our students. 
humanitarian specialties, which attracts many applicants.

However, the most popular technical specialities among the applicants were specialties the numbers of which are given in Figure 4.

At the same time, we determined the effectiveness of the carried out activities, which helps to reveal the most demanded specialties among their participants. So, applicants whose contacts were obtained at Olympiads and open days more often than on average submitted documents to technical institutes: Institute of Civil Engineering and Institute of Applied Mathematics and Mechanics; and less often applied for economic and humanitarian specialties.

Thus, the most sought-after directions were: construction, computer technology, electric power and electrical engineering, applied mathematics and mechanics, physics and nanotechnology, energy and transport systems, biotechnology, heat power and heat engineering, radiotechnics.

\section{CONCLUSIONS}

Career guidance activities conducted at universities play an important role in providing the Russian economy with highly qualified, competitive specialists in demand on the world labor market.

Nowadays, in connection with the transition to continuous multi-level professional education, this type of activity acquires special significance and becomes one of the main stages in the implementation of the ideas provided for by the

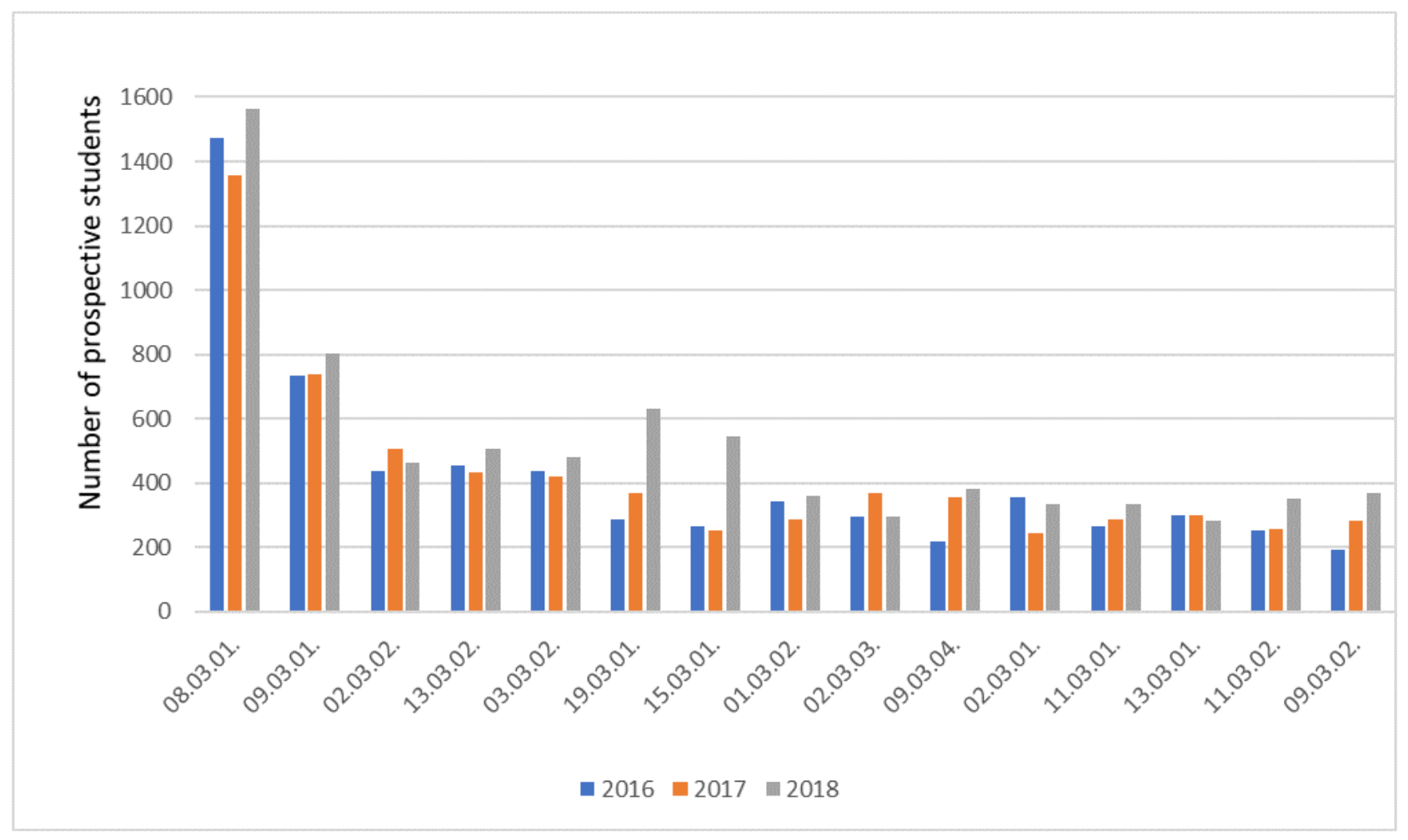

Fig, 4, The most popular technical specialties among the applicants 
[3] Zubing Luo, "Predicaments of Analytical Evaluation on High School Students' Comprehensive Quality and Its Countermeasures", Education Science, 2014, vol. 30, p.7-12.

[4] V. I. Kutugina, "Factors of professional self-identity in the modern world", Modern problemsof science and education, 2007, 1, pp. 51-53.

[5] V. V. Glukhov and N. O. Vasetskaya, "Improving the teaching quality with a smart-education system", In Proceedings of the 2017 IEEE VI Forum Strategic Partnership of Universities and Enterprises of Hi-Tech Branches, Science, Education, Innovations, SPUE, St. Petersburg, Russian Federation, 15-17 November, 2017, Shaposhnikov S. (ed.), IEEE, 2017, pp. 17-21.

[6] J. P. Greenan and R. B. Mustapha. "The role of vocational education in economic development in Malaysia: Educator's and employer's perspective", Journal of industrial teacher education", Virginia tech digital library 39 (2), 2002 [Electronic resource]. Available at: <http://scholar.lib.vt.edu/ejournals/JITE/v39n2/mustapha.html> (Accessed: 16 June 2012).

[7] "America's Choice: High Skills or Low Wages!", Commission on the Skills of the American Workforce, Rochester, NY: National Center on Education and the Economy, June, 1990 (ED 323 297).

[8] J. V. Hamby, "Vocational Education for the 21st Century", Clemson, SC: National Dropout Prevention Center, September, 1992 (ED 351 489).

[9] L. J. Shirley and S. G. Pritz, "The Lifelong Options Program: A Handbook for Implementing and Managing a Vocational Education Program for Youth at Risk", Clemson, SC: National Dropout Prevention Center, September, 1992 (ED 351 490).

[10] X. Sun and N. Wang, "Evaluation of comprehensive quality of college students based on intuitionistic fuzzy sets", Journal of Hefei University of Technology (Natural Science), 2013, vol. 36, p.1002-1005.

[11] T. V. Shushara and A. N. Khuziakhmetov, "The problem of professional orientation ofyouth: trends and prospects", Man In India, 97 (14), pp. 197-205

[12] I. U. Zulkarnay, A. I. Dashkina, and D. A. Tarkhov, "Measuring the students' level of knowledge on the basis of other students' subjective opinions", J. Phys. Conf. Ser, 2018, 1044, 012043.

[13] S. V. Krasnov, S. V. Kalmykova, E. E. Abushova, and A.S. Krasnov, "Problems of Quality of Education in the Implementation of Online Courses in the Educational Process", In Proceedings of the 2018 International Conference on High Technology for Sustainable Development (HiTech), IEEE, Sofia, Bulgaria, 11-14 June 2018, 8566618.

[14] V. N. Kruglikov, "Experiential methods of studying theory at engineering universities", Educ. Sci. J., 2018, 20, pp. 50-69. 